\title{
Influence of xylanase addition on the characteristics of loaf bread prepared with white flour or whole grain wheat flour
}

\author{
Influência da adição de xilanase nas características de pão de forma preparado com farinha de trigo comum \\ ou farinha de trigo de grão inteiro
}

\author{
Leandra Zafalon JAEKEL ${ }^{1,2 *}$, Camila Batista da SILVA², Caroline Joy STEEL ${ }^{2}$, Yoon Kil CHANG ${ }^{2}$
}

\begin{abstract}
The aim of this study was to verify the influence of the addition of the enzyme xylanase (four concentrations: $0,4,8$, and $12 \mathrm{~g}^{\circ} 100 \mathrm{~kg} \mathrm{~g}^{-1} \mathrm{flour}$ ) on the characteristics of loaf bread made with white wheat flour or whole grain wheat flour. Breads made from white flour and added with xylanase had higher specific volumes than those of the control sample (no enzyme); however, the specific volume did not differ significantly ( $\mathrm{p} \leq 0.05$ ) among the breads with different enzyme concentrations. All formulations made from whole grain wheat flour and added with xylanase also had specific volumes significantly higher than those of the control sample, and the highest value was found for the $8 \mathrm{~g} x y l a n a s e .100 \mathrm{~kg}^{-1} \mathrm{flour}$ formulation. With respect to moisture content, the formulations with different enzyme concentrations showed small significant differences when compared to the control samples. In general, breads made with the addition of $8 \mathrm{~g}$ enzyme. $100 \mathrm{~kg}^{-1}$ flour had the lowest firmness values, thus presenting the best technological characteristics.
\end{abstract}

Keywords: white wheat flour; whole grain wheat flour; xylanase; loaf bread.

\section{Resumo}

O objetivo deste estudo foi verificar a influência da adição da enzima xilanase (quatro concentrações: $0,4,8$ e 12 g.100 kg-1 de farinha) nas características de pães de forma obtidos com farinha de trigo comum ou farinha de trigo de grão inteiro. Os pães produzidos com farinha comum com adição de xilanase apresentaram maior volume específico que o controle (sem enzima), porém não diferiram significativamente $(\mathrm{p} \leq 0,05)$ dos pães com as diferentes concentrações da enzima. Todas as formulações com farinha de grão inteiro adicionadas de xilanase também apresentaram volume específico significativamente maior que o controle, sendo o maior valor encontrado na formulação com $8 \mathrm{~g}$ xilanase. $100 \mathrm{~kg}^{-1}$ de farinha. Quanto à umidade, as diferentes concentrações da enzima apresentaram pequena diferença significativa em relação ao controle. Em geral, os pães obtidos com adição de $8 \mathrm{~g}$ enzima. $100 \mathrm{~kg}^{-1}$ de farinha apresentaram os menores valores de firmeza, apresentando as melhores características tecnológicas.

Palavras-chave: farinha de trigo; farinha de trigo de grão inteiro; xilanase; pão de forma.

\section{Introduction}

Whole grain wheat flours are nutritionally superior to white flours because they have greater amounts of fiber, minerals, vitamins, phenolic compounds, phytic acid, and phytoestrogens, among other constituents (KULAWINEK et al., 2008).

Most products obtained from wheat flour are effectively fortified with certain nutritive substances, such as group B vitamins (thiamine, riboflavin, niacin, and folic acid), and iron (SLAVIN et al., 1999). According to Kulawinek et al. (2008), several studies have shown that the bioactive compounds added to food as artificial supplements are not as beneficial as those naturally present in grains. Studies correlate the consumption of whole grain products with health benefits, such as the reduction of the risk of chronic diseases like obesity, diabetes, coronary heart disease, stroke, hypertension, and some types of cancer (CHATENOUD et al., 1998; ANDERSON, 2004; KULAWINEK et al., 2008).
Although whole grain wheat flour has better nutritional and functional values, its use leads to losses to the final product in terms of technology. Therefore, the use of enzymes is an interesting alternative to produce whole grain foods (SILVA, 2007). Additionally, due to their great contribution to the improvement of bakery product quality and shelf-life, enzymes that degrade polysaccharides have been widely used (CABALLERO; GOMEZ; ROSSEL, 2007).

Arabinoxylans, also called pentosans, are the main non-starch polysaccharides in wheat flour, and are found in concentrations between 1.5 and $2.5 \%$. They can be classified as water extractable arabinoxylans (WEAX) and waterunextractable arabinoxylans (WUAX). Although they are found in small amounts in wheat flour, arabinoxylans greatly affect dough characteristics due to their unique physicochemical properties. It is frequently reported that WEAX are beneficial,

${ }^{1}$ Federal Institute Farroupilha of Education, Science and Technology - IFF, RS-377, Km 27, Passo Novo, CEP 97555-000, Alegrete, RS, Brazil

${ }^{2}$ Department of Food Technology, Faculty of Food Engineering, University of Campinas - UNICAMP, CP 6121, CEP 13083-862, Campinas, SP, Brazil, e-mail: leandrazafalon@gmail.com

${ }^{*}$ Corresponding author 
while WUAX have negative effects on bakery products; the reasons for this are not completely understood (COURTIN; DELCOUR, 2002). According to Wang et al. (2003), the negative effects of WUAX are related to their interference in the gluten network formation. Besides competing for water, making it unavailable for gluten network development, WUAX destabilize the gas cells by forming physical barriers in the gluten network during dough development (GOESAERT et al., 2005).

Xylanase enzymes randomly attack the main arabionoxylan chain (comprised of xylose units) reducing the substrate polymerization degree and, thus, releasing water and decreasing the amount of water-insoluble pentosans (ROUAU; EL HAYEK; MOREAU, 1994; COURTIN; DELCOUR, 2002). One of the consequences of WUAX solubilization is the reduction of their ability to retain water, resulting in the redistribution of water to other flour components, mainly gluten, thus increasing its extensibility (POPPER, 1997).

Xylanases improve the properties of dough handling, oven spring, and bread volume (SPRÖSSLER, 1997; COURTIN; DELCOUR, 2002). They cause a strong impact on the structure and functionality of arabinoxylans, with different baking effects, depending on the concentration and specificity of the enzyme for water-extractable arabinoxylans (WEAX) or waterunextractable arabinoxylans (WUAX) (ROUAU; EL HAYEK; MOREAU, 1994; COURTIN; DELCOUR, 2002).

Caballero, Gómez and Rosell (2007) studied the changes in dough rheology, quality, and shelf-life of breads caused by the use of enzymes and found that bread quality parameters were significantly affected by the addition of xylanase at a dosage of $6 \mathrm{mg} .100 \mathrm{~g}^{-1}$ flour. According to Rouau, El Hayek and Moreau (1994), the addition of optimum xylanase levels $(60 \mathrm{ppm})$ to flours significantly improved general dough characteristics with greater effects in weaker flours. Popper (1997) also observed an increase in the oven rise and final bread volume when the formulation was added with endoxylanase. The product obtained had a finer and softer crumb structure and longer shelf-life.

The aim of this study was to compare the influence of the addition of different xylanase concentrations to loaf bread prepared with white flour or whole grain wheat flour.

\section{Material and methods}

\subsection{Materials}

The following ingredients were used in bread production: white flour and whole grain wheat flour (Anaconda Industrial Agricola of Cereals S.A., São Paulo, SP); hydrogenated vegetable shortening (Cargill Agrícola S.A., Mairinque, SP); Lacsol powdered milk (Alibra Ingredientes Ltda., Campinas, $\mathrm{SP}$ ); Agglomerated calcium propionate (Metachem Ind. and Com. Ltda., São Paulo, SP); Zea bread improver (Emulzint, Jundiaí, SP), made from corn, and/or cassava, and/or wheat starch, and calcium carbonate, polyoxyethylene (20) sorbitan monooleate, calcium stearoyl-2-lactil lactate, ascorbic acid and alpha-amylase; Pentomax xylanase enzyme with $2000{\mathrm{U} . \mathrm{g}^{-1}}^{-1}$ activity (Prozyn Ind. e Com. Ltda., São Paulo, SP); wheat gluten
(Labonathus Biotecnologia Internacional Ltda., São Paulo, SP); Fleischmann instant baker's yeast recommended for bread and pizza (AB Brasil Ind and Com. de Alimentos Ltda., Jundiaí, SP), salt, and refined sugar.

\subsection{Characterization of white flour and whole grain wheat flours}

The flours were characterized for moisture, proteins, and ash content, according to AACC methods number 44-15A, 46-13 and 08-12 (AMERICAN.., 1995). The lipid content was determined according to the Analytical Standards of the Adolfo Lutz Institute (1985), and the carbohydrate content was determined by difference. All analyses were performed in quadruplicate, except for the determination of ash content, which was performed in quintuplicate. The dietary fiber content was obtained from the manufacturer's specifications (ANACONDA..., 2008).

\subsection{Bread production}

The formulation of the loaf bread used in this study included: $100.0 \%$ flour (white flour or whole grain wheat flour), $2.0 \%$ yeast, $2.0 \%$ salt, $4.0 \%$ sugar, $3.0 \%$ fat, $4.0 \%$ powdered milk, $0.2 \%$ calcium propionate, $1 \%$ bread improver, and water (according to the farinographic absorption: 66.0\% for white flour and $69.9 \%$ for whole grain wheat flour - flour basis). Four percent vital wheat gluten was added to the whole grain wheat flour bread formulation. The enzyme xylanase was added to the formulations at four different levels: $0,4,8$ and $12 \mathrm{~g} .100 \mathrm{~kg}^{-1}$ flour based on the manufacturer's specification that indicates the use from 4 to $10 \mathrm{~g}$ enzyme. $100 \mathrm{~kg}^{-1}$ flour. The enzyme was added directly to the flour before the other ingredients were added to the mixer.

The loaf breads were prepared using the straight dough method. The ingredients were mixed in a HAE 10 mixer (Hyppolito, Ferraz de Vasconcelos, SP, Brazil). This stage was conducted in two steps: the first step at slow speed for 5 minutes and the second at fast speed until the gluten network was completely developed. The dough was then divided into portions of $400 \mathrm{~g}$ and put at rest for 15 minutes. Then, the dough portions were modeled in a HM2 modeler (Hyppolito, Ferraz de Vasconcelos, SP, Brazil), put into greased pans, and taken to a Thermopão Maquip fermentation chamber, model 20B (Klimaquip, Pouso Alegre, MG, Brazil) for 80 minutes with temperature $\left(30{ }^{\circ} \mathrm{C}\right)$ and humidity $(80 \%)$ control. After fermentation, the dough portions were baked in a HF4B oven (Hyppolito, Ferraz de Vasconcelos, SP, Brazil) for 40 minutes at $160^{\circ} \mathrm{C}$. After baking, the breads were taken out of the pans and were placed in polypropylene bags after cooling for 2 hours, and were stored at room temperature in order to be analyzed during storage.

\subsection{Bread quality assessment}

The specific volume of breads was determined on the day they were prepared using the millet seed displacement method in triplicate. The specific volume was calculated by dividing the bread volume $(\mathrm{mL})$ by its mass $(\mathrm{g})$, according to AACC method 
number 55-50 (AMERICAN..., 1995). Bread crumb moisture and instrumental texture determinations were performed after 1,4 , and 7 days of storage, according to AACC methods number 44-15A and 74-09 (1995), respectively. Moisture was determined in triplicate and texture in 10 replicates. The parameters used in the instrumental texture analysis were: $\mathrm{P} / 35$ aluminum probe; test speed: $1.7 \mathrm{~mm} / \mathrm{s} ; 40 \%$ sample compression; pre-test speed: $1.7 \mathrm{~mm} / \mathrm{s}$; post-test speed: $3.0 \mathrm{~mm} / \mathrm{s}$; and force: $20 \mathrm{~g}$ (compression force). The dietary fiber content of breads was calculated based on the dietary fiber content of the flours obtained from the manufacturer's specifications (ANACONDA..., 2009).

\subsection{Statistical analysis}

The analysis of the results was performed using the SAS version 8.2 software and ANOVA and the Tukey test (The effect of enzyme concentration and days of storage was evaluated for each type of flour.

\section{Results and discussion}

\subsection{Proximate composition of white flour and whole grain wheat flours}

White flour moisture content was $11.08 \%$ and that of the whole grain wheat flour was $9.83 \%$. Both values are within the limit established by the Brazilian Health Ministry in Resolution RDC number 263, of 22.09.2005 (BRASIL, 2005b) for flour, which is of $15 \%$. In Brazil, there is still no regulation for whole grain wheat flour, so Normative Instruction number 8 , of 06.02.2005, of the Ministry of Agriculture (BRASIL, 2005a) was used, according to which whole wheat flour must have at least $8.0 \%$ protein content (BRASIL, 2005a). The protein content of the whole grain wheat flour studied was $10.31 \%$, higher than that of the white wheat flour (Table 1). Although the protein content of white wheat flour was lower than that of whole grain wheat flour, the technological quality of the former is better since it contains a greater amount of gluten-forming proteins (SILVA, 2007).

Ash content is directly related to fiber content, which interferes with the wheat flour quality. The ash content, as expected, was higher in whole grain wheat flour than in white wheat flour. This percentage is in accordance with Normative Instruction number 8 , which establishes that wheat flour classified as whole grain must have ash content between 1.4 and 2.5\% (BRASIL, 2005a). The ash content of white wheat flour

Table 1. Proximate composition (dry basis) of white flour and whole grain wheat flours.

\begin{tabular}{lcc}
\hline \multicolumn{1}{c}{ Constituent (\%) } & White wheat flour & Whole grain wheat flour \\
\hline Proteins & $13.97 \pm 0.13$ & $15.41 \pm 0.61$ \\
Ash & $1.39 \pm 0.02$ & $1.71 \pm 0.02$ \\
Lipids & $1.32 \pm 0.01$ & $2.12 \pm 0.04$ \\
Carbohydrates $^{\mathrm{a}}$ & 83.32 & 80.76 \\
Fiber $^{\mathrm{b}}$ & 3.00 & 12.00 \\
\hline
\end{tabular}

Means \pm standard deviation. ${ }^{\mathrm{a} C a l c u l a t e d}$ by difference (includes the dietary fiber fraction).

balues obtained from the manufacturer's specifications (ANACONDA..., 2009). was quite high (1.39\%), indicating contamination by external grain layers. However, this value is within the specifications of Normative Instruction number 8, which establishes a maximum ash value of $1.4 \%$ for type 2 flour. This content depends mainly on the wheat extraction level and also on the variety and environmental conditions, among other factors.

The lipid content of whole grain wheat flour was $60 \%$ higher than the value obtained for white wheat flour. This result was expected since whole grain wheat flour contains germ and bran, which are rich in lipids which are mostly eliminated by the milling process to obtain white wheat flour.

Regarding the carbohydrate content, the white wheat flour had higher content $(83.32 \%)$ than that of the whole grain wheat flour (80.76\%). Silva (2007) obtained $85 \%$ carbohydrates in white wheat flour and $81 \%$ in whole grain wheat flour. In whole grain wheat flour, the greater amount of other non-carbohydrate constituents, such as minerals (ash) and lipids reduce the carbohydrate content.

Dietary fiber content values are in accordance with the USDA National Nutrient Database for Standard Reference that establishes $2.4 \%$ in white wheat flour and $12.2 \%$ in whole grain wheat flour (UNITED..., 2008). Approximately 2-3\% of these fibers are arabinoxylans in the wheat flour and about $5 \%$ in the whole grain, and this type of fiber is the substrate for the enzyme xylanase (COLLINS et al., 2006).

\subsection{Loaf bread quality assessment}

One of the most important quality determinations of bread is volume, mainly in formulations using whole grain wheat flour, in which the volume tends to be lower than that of breads made with white wheat flour (SHAH; SHAH; MADAMWAR, 2006). Loaf breads presented specific volumes between 4.09 and $5.16 \mathrm{~mL} \cdot \mathrm{g}^{-1}$ (Table 2). Ishida (2012) determined the specific volume of pan breads in the Brazilian market and found mean values of $4.72 \mathrm{~mL} . \mathrm{g}^{-1}$ (white breads) and $4.70 \mathrm{~mL} . \mathrm{g}^{-1}$ (whole breads).

As can be observed, the specific volumes of breads made with white flour added with different xylanase enzyme concentrations $\left(0,4,8\right.$, and $12 \mathrm{~g} .100 \mathrm{~kg}^{-1}$ flour) did not differ significantly $(\mathrm{p} \leq 0.05)$ one from another, however, they were significantly higher than the specific volume of breads without the addition of the enzyme. All formulations differed significantly from their respective control formulations by having higher specific volume values. For the breads made with whole grain wheat flour, the formulation using $8 \mathrm{~g}$ xylanase $100 \mathrm{~kg}^{-1}$ flour was the one that had the highest specific volume. It was observed that the formulation prepared with higher xylanase concentration $\left(12 \mathrm{~g} .100 \mathrm{~kg}^{-1}\right)$ increased greatly in volume during the fermentation process; however, the breads collapsed during baking. In order to work with such a dosage, it would probably be necessary to reduce fermentation time, which was kept fixed in this study for comparison effects.

Similar results were obtained by Lai, Davis and Hoseney (1989). These authors observed that the addition of bran to white flour absorbed a great volume of water and, due to this, gluten 
Table 2. Influence of xylanase addition on quality characteristics of loaf bread produced with white and whole grain wheat flours evaluated during a 7-day storage period.

\begin{tabular}{|c|c|c|c|c|c|c|c|}
\hline \multirow{2}{*}{$\begin{array}{c}\text { Concentration } \\
\text { (g enzyme.100 kg-1 flour) }\end{array}$} & \multirow{2}{*}{$\begin{array}{l}\text { Specific } \\
\text { volume } \\
\left(\mathrm{mL} \cdot \mathrm{g}^{-1}\right)\end{array}$} & \multicolumn{3}{|c|}{$\begin{array}{c}\text { Moisture } \\
\text { content (\%) }\end{array}$} & \multicolumn{3}{|c|}{ Firmness (g) } \\
\hline & & Day 1 & Day 4 & Day 7 & Day 1 & Day 4 & Day 7 \\
\hline \multicolumn{8}{|c|}{ White wheat flour } \\
\hline 0 & $4.38 \pm 0.02^{\mathrm{b}}$ & $41.89 \pm 0.11^{\mathrm{abA}}$ & $41.28 \pm 0.19^{\mathrm{aB}}$ & $39.99 \pm 0.29^{\mathrm{bC}}$ & $215.41 \pm 81.05^{\mathrm{aB}}$ & $218.21 \pm 16.87^{\mathrm{aB}}$ & $354.45 \pm 50.98^{\mathrm{aA}}$ \\
\hline 4 & $5.16 \pm 0.11^{\mathrm{a}}$ & $42.13 \pm 0.33^{\mathrm{aA}}$ & $41.67 \pm 0.20^{\mathrm{aA}}$ & $40.73 \pm 0.08^{\mathrm{aB}}$ & $183.15 \pm 16.01^{\mathrm{bC}}$ & $239.55 \pm 28.01^{\mathrm{aB}}$ & $328.66 \pm 36.36^{\mathrm{aA}}$ \\
\hline 8 & $5.14 \pm 0.05^{\mathrm{a}}$ & $41.55 \pm 0.24^{\mathrm{bA}}$ & $41.41 \pm 0.29^{\mathrm{aA}}$ & $39.80 \pm 0.34^{\mathrm{bB}}$ & $134.61 \pm 16.06^{\mathrm{cB}}$ & $211.00 \pm 38.76^{\mathrm{aA}}$ & $254.73 \pm 42.52^{\mathrm{bA}}$ \\
\hline 12 & $5.12 \pm 0.14^{\mathrm{a}}$ & $42.13 \pm 0.08^{\mathrm{aA}}$ & $42.36 \pm 1.26^{\mathrm{aA}}$ & $40.22 \pm 0.35^{\mathrm{abB}}$ & $206.55 \pm 37.33^{\mathrm{bA}}$ & $235.59 \pm 43.51^{\mathrm{aA}}$ & $299.64 \pm 79.72^{\mathrm{abA}}$ \\
\hline \multicolumn{8}{|c|}{ Whole grain wheat flour } \\
\hline 0 & $4.09 \pm 0.10^{c}$ & $42.58 \pm 1.43^{\mathrm{aA}}$ & $43.87 \pm 0.52^{\mathrm{aA}}$ & $40.23 \pm 3.53^{\mathrm{aA}}$ & $240.93 \pm 19.38^{\mathrm{aB}}$ & $260.13 \pm 40.17^{\mathrm{aAB}}$ & $305.65 \pm 21.04^{\mathrm{aA}}$ \\
\hline 4 & $4.66 \pm 0.12^{\mathrm{b}}$ & $43.76 \pm 0.11^{\mathrm{aB}}$ & $44.44 \pm 0.19^{\mathrm{aA}}$ & $42.55 \pm 0.30^{\mathrm{aC}}$ & $182.67 \pm 28.40^{\mathrm{bB}}$ & $233.47 \pm 26.17^{\mathrm{abAB}}$ & $264.25 \pm 19.18^{\mathrm{bA}}$ \\
\hline 8 & $4.96 \pm 0.14^{\mathrm{a}}$ & $43.72 \pm 0.21^{\mathrm{aA}}$ & $43.62 \pm 0.34^{\mathrm{aA}}$ & $39.41 \pm 5.85^{\mathrm{aA}}$ & $168.22 \pm 22.14^{\mathrm{bB}}$ & $202.96 \pm 19.31^{\mathrm{bAB}}$ & $224.50 \pm 26.39^{\mathrm{cA}}$ \\
\hline 12 & $4.49 \pm 0.07^{\mathrm{b}}$ & $43.30 \pm 0.41^{\mathrm{aA}}$ & $43.80 \pm 1.31^{\mathrm{aA}}$ & $43.30 \pm 3.36^{\mathrm{aA}}$ & $215.11 \pm 19.89^{\mathrm{aB}}$ & $256.08 \pm 25.14^{\mathrm{aAB}}$ & $289.79 \pm 27.09^{\mathrm{abA}}$ \\
\hline
\end{tabular}

Means \pm standard deviation. Means with different lowercase letters in the same column (and for the same flour) indicate significantly difference ( $\mathrm{p} \leq 0.05$ ). Means with different uppercase letters in the same row (and for the same flour) indicate significantly difference $(\mathrm{p} \leq 0.05)$ for moisture content and firmness separately.

was not completely hydrated resulting in breads with smaller volumes. Norma and Guillermo (2003) observed a bread volume increase of approximately $30 \%$ with a concentration of $25 \mathrm{ppm}$ xylanase, but with concentrations of 150 and 200 ppm of this enzyme, the volume was similar to the control sample without xylanase. Jiang et al. (2005) also observed an increase in bread specific volume with the use of different xylanase dosages ( 0 to $100 \mathrm{ppm}$ ) and the greatest volume was obtained with $40 \mathrm{ppm}$ of the enzyme ( $41.4 \%$ higher than that of the control).

With respect to moisture (Table 2), on days 1 and 4, the loaf breads made from white wheat flour with different xylanase concentrations did not show any significant difference ( $\mathrm{p} \leq 0.05$ ) when compared to the formulation without enzyme. In addition, on day 7 of storage, only the formulation prepared using 4 g. $100 \mathrm{~kg}^{-1}$ had moisture content significantly higher than that of the formulation without enzyme. There was no significant difference between the moisture values of whole grain wheat flour loaf breads made from different enzyme concentrations on the storage days assessed.

The moisture content of the breads with white wheat flour and no enzyme ( 0 g.100 $\left.\mathrm{kg}^{-1}\right)$ on the different days of analysis (days 1, 4 and 7) differed significantly ( $\mathrm{p} \leq 0.05$ ). The white breads with 4, 8, and $12 \mathrm{~g}$ enzyme. $100 \mathrm{~kg}^{-1}$ flour presented similar behavior, i.e., they did not differ significantly on days 1 and 4 , and showed a difference (reduction) on day 7.

The moisture content of whole grain wheat flour breads differed only from those with $4 \mathrm{~g}$ enzyme. $100 \mathrm{~kg}^{-1}$ flour on the 3 days of analysis. For the whole grain breads with 8 and $12 \mathrm{~g}$ enzyme. $100 \mathrm{~kg}^{-1}$, the moisture content did not differ during the storage period proving effective in maintaining bread freshness.

The moisture content of the breads after 4 days of storage was very close to that of the first day, and this behavior was observed for both flours used. On the other hand, on day 7 there was moisture reduction in both formulations (with white and whole grain wheat flour). In a study conducted with whole grain wheat flour, Silva (2007) found similar moisture content values, within the 41.18 and $44.54 \%$ range. Figure 1 shows the moisture content values of loaf breads during the storage period. Due to the redistribution of moisture between the crumb and the crust, the reduction of these values after 7 days can be noticed.

With respect to firmness (Table 2), it was observed that for both types of breads there was an increase during the storage period. The hardening of the crumb can be assigned to the different starch crystallization forms, protein and pentosan structural changes, and also to the moisture loss of bread after baking (OVADIA; WALKER, 1996; ESTELLER et al., 2004). Bread firmness values with different enzyme concentrations differed significantly from those of the control sample on day 1 , except for the bread with whole grain wheat flour and 12 g xylanase. $100 \mathrm{~kg}^{-1}$ flour.

The firmness of breads with white wheat flour and $8 \mathrm{~g}$ enzyme.100 $\mathrm{kg}^{-1}$ flour was significantly ( $\left.\mathrm{p} \leq 0.05\right)$ lower than that of the others, and the control formulation had the highest crumb firmness value. On the last day of analysis, only breads with $8 \mathrm{~g} .100 \mathrm{~kg}^{-1}$ differed significantly $(\mathrm{p} \leq 0.05)$ from the control sample; however, they did not differ significantly from breads with $12 \mathrm{~g}$ enzyme. $100 \mathrm{~kg}^{-1}$ flour. This indicates that the higher enzyme concentrations tested in this study resulted in lower bread crumb firmness after storage.

The whole grain wheat flour breads with xylanase in the concentrations of 4 and $8 \mathrm{~g} .100 \mathrm{~kg}^{-1}$ flour on the first day had lower firmness values and were significantly different $(\mathrm{p} \leq 0.05)$ from the others. On day 7 of storage, the formulation with $8 \mathrm{~g} .100 \mathrm{~kg}^{-1}$ was the one that had the lowest firmness value and significantly differed $(\mathrm{p} \leq 0.05)$ from the other formulations.

Comparing texture on the different storage days, only the firmness values of the breads with white wheat flour and 12 g enzyme. $100 \mathrm{~kg}^{-1}$ flour did not differ significantly $(\mathrm{p} \leq 0.05)$ on different days. The breads with whole grain wheat flour $\left(0,4,8\right.$, and 12 g enzyme.100 $\mathrm{kg}^{-1}$ flour) had similar behavior in relation to firmness: no statistical differences were found between days 4 and 7 or between days 1 and 4 . 


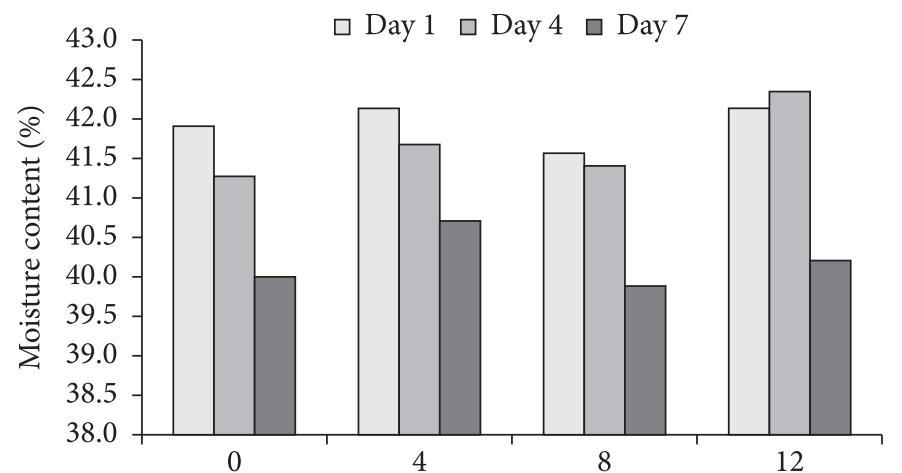

Concentration enzyme (g.100 kg-1 white wheat flour)

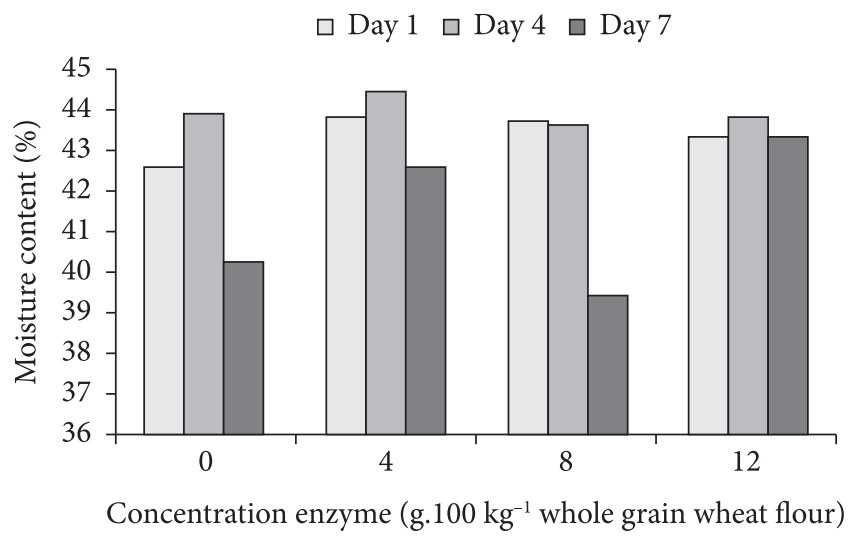

Figure 1. Moisture content of loaf breads made from white wheat flour (WWF) and whole grain wheat flour (WGWF), with different xylanase concentrations, during the storage period.

$\square$ Day 1 Day 4 ㅁ Day 7

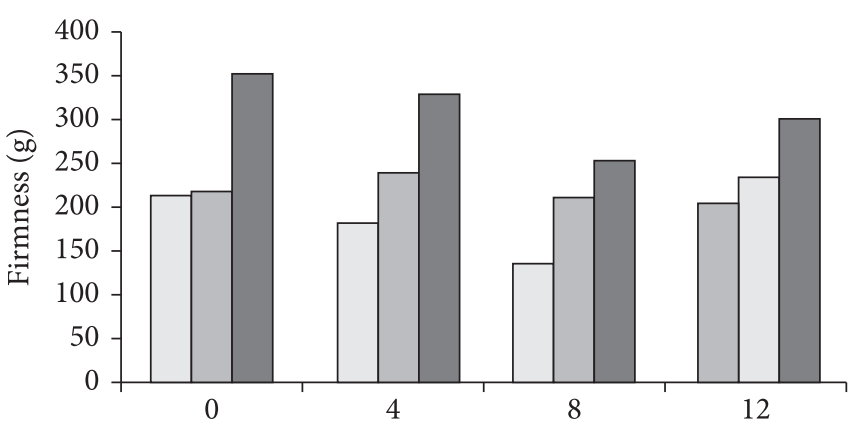

Concentration enzyme (g.100 kg-1 white wheat flour)

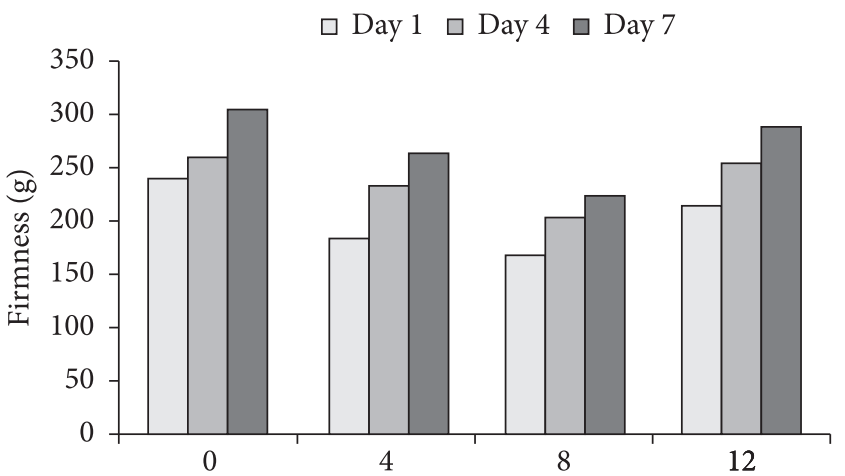

Concentration enzyme (g.100 kg-1 whole grain wheat flour)

Figure 2. Firmness of loaf breads made from white wheat flour (WWF) and whole grain wheat flour (WGWF), with different xylanase concentrations, during the storage period.

In Figure 2, the effect of xylanase addition on bread texture can be observed. The $8 \mathrm{~g} .100 \mathrm{~kg}^{-1}$ flour dosage was the most adequate concentration used in this study. The enzyme xylanase promoted better development of the gluten network, which in turn promotes an increase in bread volume and a reduction in crumb firmness during storage.

Similar behavior was observed in a study on the influence of different enzyme concentrations on wheat flour bread characteristics, in which the firmness of breads with the addition of $40 \mathrm{ppm}$ xylanase decreased up to 21.4\% (JIANG et al., 2005). Shah, Shah and Madamwar (2006) obtained significantly reduced firmness (77\%) when adding the enzyme xylanase to their formulation, and this reduction was assigned to the increase of bread volume.

The present study demonstrated that the addition of the enzyme xylanase influenced the quality of loaf breads prepared with white wheat flour and with whole grain wheat flour.

The dietary fiber content of the breads was calculated based on the values obtained from the flour manufacturer's specifications. Breads produced with white wheat flour had approximately $1.6 \%$ dietary fiber, while those produced with whole grain wheat flour had dietary fiber content ranging from
5.9 to $6.2 \%$, which means an increase of 3.5 times. Therefore, the use of whole grain wheat flour improves bread functional quality due to the presence of fibers, antioxidants, phenolic compounds, among other bioactive compounds.

\section{Conclusions}

Breads made with white wheat flour had greater specific volume; however, it was possible to produce good quality loaf breads using whole grain wheat flour, and the most adequate enzyme concentration was $8 \mathrm{~g}$ xylanase $100 \mathrm{~kg}^{-1}$ flour.

Regarding moisture content, breads prepared with white flour had lower values when compared to those prepared with whole grain flour. All formulations had lower moisture contents at the end of the storage period. Among the breads made from white flour, only those with $4 \mathrm{~g}$ xylanase $100 \mathrm{~kg}^{-1}$ flour differed significantly from the control during storage. Among those made from whole grain flour and xylanase and the control, there was no significant difference.

The addition of the enzyme xylanase also influenced bread texture, and the addition of $8 \mathrm{~g}$ xylanase $100 \mathrm{~kg}^{-1}$ flour promoted the lowest crumb firmness values for both breads. 
Therefore, it was concluded that the addition of xylanase can contribute to the improvement of the technological characteristics of breads made from white wheat flour and whole grain wheat flour. The dosage of $8 \mathrm{~g}$ xylanase. $100 \mathrm{~kg}^{-1}$ flour yielded higher specific volume and lower firmness.

\section{Acknowledgements}

The authors would like to thank the companies who kindly donated the raw materials necessary to conduct this study and the Coordination for the Improvement of Higher Education Personnel (CAPES) for granting scholarships.

\section{References}

AMERICAN ASSOCIATION OF CEREAL CHEMISTS - AACC. Approved methods of the American Association of Cereal Chemists. 9th ed. Saint Paul: AACC, 1995. v. 1, v. 2.

ANACONDA INDUSTRIAL E AGRÍCOLA DE CEREAIS S. A. Disponível em: <http://www.anaconda.com.br>. Acesso em: nov. 2009.

ANDERSON, J. W. Whole grains and coronary heart disease: The whole kernel of truth. The American Journal of Clinical Nutrition, v. 80, p. 1459-1460, 2004.

BRASIL. Ministério da Agricultura e do Abastecimento. Instrução Normativa $\mathrm{n}^{\circ} 8$, de 02 de junho de 2005. Aprovar o regulamento técnico de identidade e qualidade da farinha de trigo. Diário Oficial da República Federativa do Brasil, Brasília, DF, 03 jun. 2005a. Seção 1. Disponível em: <http://www.anvisa.gov.br>. Acesso em: nov. 2008.

BRASIL. Ministério da Saúde. Resolução RDC n 263, de 22 de setembro de 2005. Aprovar o regulamento técnico para produtos de cereais, amidos, farinhas e farelos. Diário Oficial da República Federativa do Brasil, Brasília, DF, set. 2005b. Disponível em: $<$ http://www.anvisa.gov.br>. Acesso em: nov. 2008.

CABALlERO, P. A.; GÓMEZ, M.; ROSELL, C. M. Improvement of dough rheology, bread quality and bread shelf-life by enzymes combination. Journal of Food Engineering, v. 81, n. 1, p. 42-53, 2007. http://dx.doi.org/10.1016/j.jfoodeng.2006.10.007

CHATENOUD, L. et al. Whole grain food intake and cancer risk. International Journal of Cancer, v. 77, p. 24-28, 1998. http:// dx.doi.org/10.1002/(SICI)1097-0215(19980703)77:1\%3C24::AIDIJC5\%3E3.0.CO;2-1

COLLINS, T. et al. Use of glycoside hydrolase family 8 xylanases in baking. Journal of Cereal Science, v. 43, p. 79-84, 2006. http:// dx.doi.org/10.1016/j.jcs.2005.08.002

COURTIN, C. M.; DELCOUR, J. A. Arabinoxylans and endoxylanases in wheat flour bread-making. Journal of Cereal Science, v. 35, p. 225-243, 2002. http://dx.doi.org/10.1006/jcrs.2001.0433

ESTELLER, M. S. et al. Uso de açúcares em produtos panificados. Ciência e Tecnologia de Alimentos, v. 24, n. 4, p. 602-607, 2004. http://dx.doi.org/10.1590/S0101-20612004000400021

GOESAERT, H. et al. Wheat flour constituents: how they impact bread quality, and how to impact their functionality. Trends in Food Science \& Technology, v. 16, p. 12-30, 2005. http://dx.doi. org/10.1016/j.tifs.2004.02.011
INSTITUTO ADOLFO LUTZ - IAL. Normas analíticas do Instituto Adolfo Lutz. 3. ed. São Paulo: IAL, 1985. v. 1, 533 p.

ISHIDA, P. M. G. Efeito de diferentes fontes de fibras brancas na qualidade de pão de forma. 2012. 204 f. Dissertação (Mestrado em Tecnologia de Alimentos)-Universidade Estadual de Campinas, Campinas, 2012.

JIANG, Z. et al. Improvement of the bread making quality of wheat flour by the hyperthermophilic xylanase from Thermotoga maritime. Food Research International, v. 38, p. 37-43, 2005. http://dx.doi. org/10.1016/j.foodres.2004.07.007

KULAWINEK, M. et al. Alkylresorcinols in selected Polish rye and wheat cereals and whole-grain cereal products. Journal of Agricultural and Food Chemistry, v. 56, p. 7236-7242, 2008. PMid:18666777. http://dx.doi.org/10.1021/jf801707g

LAI, C. S.; DAVIS, A. B.; HOSENEY, R. C. Functional effect of bran in bread-making. Journal of Cereal Chemistry, v. 66, p. 217-219, 1989.

NORMA, A. C.; GUILLERMO, A. O. Production, purification and characterization of a low-molecular-mass xylanase from Aspergillus sp. and its application in baking. Applied Biochemistry and Biotechnology, v. 104, p. 159-171, 2003. http://dx.doi.org/10.1385/ ABAB:104:3:159

OVADIA, D. Z.; WALKER, C. E. Re-examination of the bread firming curve. Starch/Staerke, v. 48, n. 4, p. 137-144, 1996.

POPPER, L. Simple approaches for identification of baking active xylanases. In: ANGELINO, S. A. G. F. et al. (Eds.). The first European symposium on enzymes and grain processing. Zeist: TNO Nutrition and Food Research Institute, 1997. 1997. p. 110-120.

ROUAU, X.; EL HAYEK, M. L., MOREAU, D. Effect of an enzyme preparation containing pentosanases on the bread-making quality of flours in relation to changes in pentosan properties. Journal of Cereal Science, v. 19, p. 259-272, 1994. http://dx.doi.org/10.1006/ jcrs.1994.1033

SHAH, A. R.; SHAH, R. K.; MADAMWAR, D. Improvement of the quality of whole wheat bread by supplementation of xylanase from Aspergillus foetidus. Bioresource Technology, v. 97, n. 16, p. 2047-2053, 2006. PMid:16307877. http://dx.doi.org/10.1016/j. biortech.2005.10.006

SILVA, C. B. Efeito da adição de xilanase, glicose oxidase e ácido ascórbico na qualidade do pão de forma de farinha de trigo de grão inteiro. 2007. 148 f. Dissertação (Mestrado em Tecnologia de Alimentos)-Universidade Estadual de Campinas, Campinas, 2007.

SLAVIN, J. L. et al. Plausible mechanisms for the protectiveness of whole grains. The American Journal of Clinical Nutrition, v. 70, p. 459-463, 1999.

SPRÖSSLER, B. G. Xylanases in baking. In: ANGELINO, S. A. G. F. et al. (Eds.). The first European symposium on enzymes and grain processing. Zeist: TNO Nutrition and Food Research Institute, 1997. p. 177-187.

UNITED STATES DEPARTMENT OF AGRICULTURE - USDA. National Nutrient Database for Standard Reference, Release 21, 2008. Disponível em: <http://www.nal.usda.gov/fnic/ foodcomp/search/>. Acesso em: dez. 2008.

WANG, M. et al. Effect of water unextractable solids on gluten formation and properties: mechanistic considerations. Journal of Cereal Science, v. 37, n. 1, p. 55-64, 2003. http://dx.doi.org/10.1006/ jcrs.2002.0478 